\title{
Escravos ameríndios e negros africanos: uma história conectada Teorias e modelos de discriminação no império português ${ }^{1}$ (ca. 1450-1650)
}

Giuseppe Marcocci

O objetivo do presente artigo é fazer uma incursão na história conectada dos dois grupos mais discriminados do império português da época moderna, dando particular atenção ao caso da sociedade colonial brasileira: os ameríndios e os negros africanos escravizados. Essa história é resultante de uma complexa teia formada por causas de diversas naturezas. Examinamos aqui três delas: o juízo acerca da capacidade de trabalho, a influência do paradigma antijudaico e o debate sobre a salvação da alma dos ameríndios e dos negros africanos.

Palavras-chave: Discriminação - hierarquias sociais - escravidão

\section{Amerindian and Black African slaves: a connected history}

Discrimination theories and models in the Portuguese Empire (ca. 1450-1650) This article aims to move toward a connected history of the two more discriminated groups in the early modern Portuguese Empire, with special regard to Brazilian colonial society: the enslaved Amerindians and Black Africans. Entangled factors marked that history. Three of them are here considered: the judgment about working capacity, the influence of anti-Judaism and the debate on the eternal salvation of Amerindians and Black Africans.

Keywords: Discrimination - social hierarchies - slavery

\footnotetext{
${ }^{1}$ Artigo recebido e aprovado para publicação em julho de 2010.

${ }^{2}$ Pesquisador da Scuola Normale Superiore di Pisa. E-mail: g.marcocci@sns.it
} 


\section{Esclaves amérindiens et noirs africains: une histoire connectée}

\section{Théorie et modèles de discrimination dans l'Empire Portugais (ca. 1450-1650)}

Le but du présent article est de réaliser une incursion dans une histoire connectée des deux des groupes les plus discriminés de l'Empire Portugais de l'Époque Moderne, en accordant une attention particulière aux cas de la société coloniale brésilienne: les Amérindiens et les noirs africains soumis à l'esclavage. Cette histoire est le résultat d'une toile complexe constituée de causes de diverses natures. Nous examinons ici trois de ces causes: le jugement sur la capacité de travail, l'influence du paradigme antijudaïque et le débat sur le salut de lâme des amérindiens et des noirs africains.

Mots-clé: Discrimination - hiérarchies sociales - esclavage

\section{Escravidões conectadas: trabalho e hierarquia}

Vou partir de dois documentos escritos com cerca de um século de distância um do outro. Trata-se em ambos os casos de uma interpelação, feita ao rei de Portugal por colonos residentes no Brasil, sobre a questão do trabalho dos escravos.

Havia passado cerca de sete anos da chegada do primeiro governador geral, D. Tomé de Sousa (1549-1553), quando autoridades municipais e moradores portugueses de Salvador da Bahia dirigiram a D. João III o específico e fundamentado pedido de uma autorização do rei para armar navios a serem enviados para São Tomé e Cabo Verde a fim de dar início a um singular comércio de escravos: índios tupinambás em troca de negros africanos "da Guiné". A alegação era que estes últimos eram muito mais úteis e confiáveis do que os nativos ("os naturais"). Argumentava-se que um uso maior de escravos africanos levaria "muito proveito ao povo, serviço a Vossa Alteza com o aumento das suas remdas e seguridade da terra". ${ }^{3}$ Voltarei a tratar das opiniões etnográficas dos colonos da Bahia. No entanto, o que interessa primeiro é observar como, em lugares e épocas diferentes, podemos encontrar ecos de uma percepção análoga, o que demonstra o segundo documento a ser examinado.

Em meados do século XVII, a região setentrional do Maranhão não tinha mais do que uma colonização embrionária. Numa consulta de 1639, a Mesa da Consciência e Ordens, tribunal régio especialmente incumbido de dirimir ou prevenir as controvérsias causadas pela intervenção da coroa em matérias de natureza

\footnotetext{
${ }^{3}$ Carta de 18 de setembro de 1556, In: As Gavetas da Torre do Tombo, ed. António da Silva Rego, Lisboa, Centro de Estudos Históricos Ultramarinos, 1974, t. 10, pp. 433-437.
} 
espiritual, manifestava grande entusiasmo em relação aos milhares de "gentios" que lá moravam e que prometiam, uma vez convertidos e sujeitados às leis e aos costumes dos colonos, contribuir para a riqueza da monarquia. Mas já em 1651, em um memorial apresentado à corte de $\mathrm{D}$. João IV, deplorava-se com veemência o miserável estado de uma capitania como o Maranhão, que dispunha apenas de mão de obra indígena, diferentemente de outros lugares do Brasil, onde a cada mês chegava da costa da África ocidental um grande contingente de escravos. ${ }^{4}$

Um aspecto geral une o documento de 1556 com o de 1651 citados aqui: ambos mostram que, na fase de assentamento em um território novo, os negros africanos desde logo resultavam ser mão de obra mais apreciada do que os índios. Quem manifestava esta preferência era especificamente a categoria dos colonos (moradores). ${ }^{5}$ Os argumentos apresentados no primeiro testemunho (subentendidos também no segundo) apontam para um rastro precoce daquela classificação comparativa dos grupos humanos destinada a inspirar as coleções etnográficas surgidas no mundo lusitano entre final do século XVIII e o início do século XIX. ${ }^{6}$ Classificação baseada, contudo, em considerações de caráter exclusivamente prático, pois propunha, de fato, uma hierarquia fundada no trabalho: segundo os primeiros habitantes da Bahia, os índios teriam características inferiores ("são muito incertos") quando comparados com os negros africanos, aptos a garantir maior resistência física ("são pera muito mais serviço"), além de uma ajuda efetiva em caso de ataque armado ("aproveitão outrosy pera ajudarem a deffemder a terra"). $\mathrm{Na}$ fase inicial da colonização, aquela visão, destinada a receber crédito a longo prazo, alimentava-se da imagem da resistência feroz que os índios souberam opor aos dominadores europeus, entre embates militares e revoltas. A desconfiança para com estes últimos nascia também da debilitação dos corpos, minados por epidemias e pela carga excessiva de trabalho forçado. Além disso, os colonos perceberam as limitações referente à redução dos índios à escravidão impostas pela

\footnotetext{
${ }^{4}$ As duas fontes são referidas por Dauril Alden, "Indian versus Black Slavery in the State of Maranhão during the Seventeenth and Eighteenth Centuries", In: Richard L. Garner, William B. Taylor (eds.), Iberian colonies, New World Societies: Essays in memory of Charles Gibson, University Park, PA, Pennsylvania State University Press, 1986, pp. 71-102: 72 e 76 (respectivamente).

${ }^{5}$ Sobre o papel particular, na época, dos colonos da Bahia cf. Pedro Puntoni, "Como coração no meio do corpo.' Salvador capital do Estado do Brasil”, In: Laura de Mello e Souza, Junia Ferreira Furtado, Maria Fernanda Bicalho (orgs.), O governo dos povos, São Paulo, Alameda, 2009, pp. 371-387.

${ }^{6}$ Ronald Raminelli, “Povos do império”, In: Souza, Furtado, Bicalho (orgs.), op. cit., p. 153-169.
} 
legislação régia como um pesado obstáculo. A constância com que se esforçaram em preservar um conjunto normativo que lhes deixasse plena faculdade de dispor dos índios como mão de obra forçada confirma, contudo, que, apesar das objeções apresentadas em cartas e memoriais, conforme os que citamos acima, os colonos continuaram durante séculos a servir-se do trabalho de escravos índios. ${ }^{7}$

Hebe Maria Mattos demonstrou como as formas de legitimação da escravidão dos negros africanos desde a metade do século XV e, mais em geral, o trabalho forçado no quadro da economia colonial têm importância fundamental para se entender a gênesis e a estrutura do Império português, assim como a sociedade colonial que aquele tipo de domínio criou. ${ }^{8}$ Deste ponto de vista, a história dos escravos ameríndios e negros africanos representa uma via privilegiada para se estudar as relações entre discriminação social e Império. De certa forma, tratou-se de uma história unitária, porque desde a metade do século XVI, especialmente no mundo atlântico, as condições de vida de uns estavam estreitamente ligadas a dos outros. Isso abre espaço para a tentativa de fazer uma história conectada entre os escravos ameríndios e os negros africanos, segundo o modelo de análise formulado por Sanjay Subrahmanyam e retomado por muitos historiadores, entre os quais se destaca Serge Gruzinski. ${ }^{9} \mathrm{O}$ experimento que vou propor aqui se concentra sobre três aspectos distantes entre si, mas de importância fundamental para entender o contexto cultural em que se realizou a multisecular exploração de homens que uniu os dois continentes de África e América: o juízo acerca da capacidade de trabalho, a herança do antijudaísmo e as visões teológicas acerca da salvação da alma.

Voltemos aos colonos do Brasil. A preferência pelos negros africanos se fundava também num elemento mais difícil de se medir, mas nem por isso menos importante: a convicção, que se espalhou rapidamente, de que os índios seriam inconstantes por natureza. Esse preconceito foi desde logo compartilhado entre missionários e colonos: a conversão das populações originárias do Brasil seria

\footnotetext{
${ }^{7}$ Também e ainda mais do que na América espanhola, no Brasil "the Indians were widely considered an expendable commodity of no redeeming value save as brute laborers" (Alden, op. cit., p. 100).

${ }^{8}$ Hebe Maria Mattos, "A escravidão moderna nos quadros do Império português: o Antigo Regime em perspectiva atlântica”, In: João Fragoso, Maria Fernanda Bicalho, Maria de Fátima Gouvêa (orgs.), O Antigo Regime nos trópicos. A dinâmica imperial portuguesa (séculos XVI-XVIII), Rio de Janeiro, Civilização Brasileira, 2001, pp. 141-162.

9 Sanjay Subrahmanyam, "Connected Histories: Notes toward a Reconfiguration of Early Modern Eurasia”, Modern Asian Studies, 31 (1997), pp. 735-762; Serge Gruzinski, "Les mondes mêlés de la Monarchie catholique et autres 'connected histories"', Annales HSS, 56 (2001), pp. 85-117.
} 
instável devido à sua fácil propensão tanto para se abrir a uma nova fé, como para abandoná-la; da mesma forma teriam demonstrado escasso pendor pelo trabalho e uma extraordinária indolência. A alusão ao esforço necessário aos missionários para favorecer o amadurecimento religioso deles rapidamente se somou à frustração dos colonos, que esperavam resultados melhores dos índios usados nas lavouras e nos engenhos de açúcar. Sobre este cenário, o antropólogo Eduardo Viveiros de Castro escreveu páginas de grande fineza, partindo de uma metáfora sugerida por Antônio Vieira em meados do século XVII, e longamente usada pela historiografia moderna, a saber, aquela do índio como uma "estátua de murta":

A estátua de murta é fácil de formar, pela docilidade com que se dobram os ramos, mas é necessário ficar sempre vigiando e trabalhando nela, para que guarde sua forma. Se o jardineiro deixar de assistir, em quatro dias sai um ramo que lhe atravessa os olhos, outro que lhe descompõe as orelhas, mais dois que de cinco dedos lhe fazem sete, e o que pouco antes era homem, já é uma confusão verde de murtas. ${ }^{10}$

Esta imagem "não foi registrada apenas para as coisas da fé. Ela passou, na verdade, a ser um traço definidor do caráter ameríndio". ${ }^{11} \mathrm{E}$ foi exatamente à procura de um remédio para esse limite atribuído aos índios, que missionários e colonos se juntaram na defesa das virtudes do trabalho forçado como forma não somente de catequese, mas também de educação civil. Na segunda metade do século XVI, o jesuíta espanhol José de Acosta desenhou a evolução histórica de uma hierarquia social fundada no trabalho que, na época, colocava no mesmo plano dois grupos humanos que para os colonos eram bem distintos:

Em definitiva, estas nações bárbaras, sobretudo os povos de África e das Índias ocidentais, devem ser educadas conforme se fez com o povo judaico e carnal, de maneira que mediante uma saudável carga de trabalhos contínuos se afastem da ociosidade e das paixões e, refreados por um temor induzido, cumpram apenas o seu dever. Tanto os exemplos do passado, quanto a recente e quotidiana experiência dos mais avisados confirmam isto abundantemente e com toda claridade. Esta é a rédea e o jugo que o sabedor aconselha, esta a barra e a carga. Deste modo, se constrange até os que não querem a entrar na salvação. ${ }^{12}$

${ }^{10}$ Castro, op. cit., p. 186.

${ }^{11}$ Idem.

12 "Itaque hebraei atque carnalis populi more maxime regendas esse nationes barbaras has, praesertim aethiopum et indorum occidentalium gentes, uti et per occupationem assiduarum salutare onus ab otio et libidine revocentur et per timore incussi fraenum in officio contineantur, cum antiquae aetatis exempla tum vero copiosissie ac manifestissime declaravit. Hoc est enim lorum et 
Enquanto o modelo desenhado por Acosta encontrou plena aplicação nos trópicos, na dura realidade das plantações, a ausência, em seus escritos de referências à oposição entre escravos índios e negros africanos, que ao contrário é frequente nas fontes produzidas pelos colonos, se explica pela adoção dos jesuítas de um critério de avaliação que interpretava o trabalho não como termômetro das qualidades humanas, mas como meio eficaz para garantir o objetivo da salvação, ou seja, como catequese.

Ainda Acosta, ao escrever anos depois dos grandes debates castelhanos sobre a natureza e os direitos dos ameríndios culminados com a célebre disputa entre Juan Ginés de Sepúlveda e o frade dominicano Bartolomé de las Casas (15501551), no prólogo de De procuranda Indorum salute - tratado publicado em 1588, mas escrito em 1576, baseado no observatório do Peru - propôs uma hierarquia dos povos com os quais os europeus entraram em contato nos novos mundos. ${ }^{13}$ Diferentemente dos colonos do Brasil, a preocupação eminentemente teológica o levou a apresentar uma classificação tripartida com base nas faculdades intelectuais (recta ratio) e no tipo de consórcio social instaurado (a consuetudo generis humani, resumida na tríade mores, ritus, leges). O último degrau de sua escala etnográfica era ocupado por índios que respondiam à descrição de portugueses sobre os homens encontrados nas costas americanas: "Homens selvagens semelhantes a bestas, os quais mal têm algum sentimento humano. Sem lei, sem rei, sem magistrados nem governo, mudam de domicílio repetidas vezes, $\mathrm{e}$ mesmo quando o tem fixo, mais parece uma caverna de feras ou um estábulo de animais." ${ }^{14}$ As comunidades africanas de onde provinham os escravos não foram citadas de maneira explícita por Acosta, mas pelas características que, na época, eram consideradas em geral pelos missionários europeus, podiam também fazer parte da terceira classe, na qual se incluía "um outro tipo de bárbaros pacíficos,

iugum quod sapiens commendat, haec virga et onus. Hoc modo ad salutem vel inviti compelluntur intrare" (José de Acosta, De Procuranda Indorum Salute, por Luciano Pereña et al., Madrid, CSIC, 1984, vol. 1, p. 146). Tradução do autor do texto.

${ }^{13}$ Para uma introdução geral permanecem insuperadas as páginas de Anthony Pagden, The fall of natural man. The American Indian and the origins of comparative ethnology, 2nd. ed. with correction and additions, Cambridge, Cambridge University Press, 1986, p. 146.

14 "Homines sylvestres feris similes, vix quicquam humani sensus habentes, sine lege, sine rege, sine certo magistratu et republica, sedes identidem commutantes aut ita fixas habentes, ut magis ferarum specus aut pecorum caulas imitentur" (Acosta, op. cit., vol. 1, p. 66). Tradução do autor do texto. 
mas de juízo muito fraco, os quais parecem um pouco superiores em relação aos outros, apresentando alguma forma de governo, apesar de terem leis e cultos semelhantes a bagatelas". ${ }^{15}$

O silêncio de Acosta sobre os negros africanos (de toda forma apontados mais adiante como "homens bárbaros semelhantes a bestas") não surpreende, dado que, conforme veremos, a reflexão teórica sobre as condições de sua salvação era muito menos adiantada, na época, quando comparada àquela referente aos índios. ${ }^{16}$ Deste ponto de vista, o De procuranda Indorum salute marcou um epílogo e um ponto de partida. Depois de sua publicação, começou a se desenvolver um debate real também sobre a conversão dos escravos africanos, a partir do exame meticuloso que outro jesuíta, Luis de Molina, dedicou-lhe no livro I de seu De iustitia et iure (1593). ${ }^{17} \mathrm{O}$ surgimento daquela nova sensibilidade missionária assume importância especial quando se observa que ela acompanha o que Stuart Schwartz aponta como uma fase de virada da relação existente entre o recurso à escravidão dos índios e àquela dos negros no Brasil. De fato, foi em meados dos anos setenta do século XVI que os escravos vindos da África, os mais caros, começaram a suplantar a mão de obra forçada das populações locais. ${ }^{18}$

Mais uma vez, os colonos forneceram uma confirmação imediata da difusão de uma visão conectada dos dois grupos no mundo brasileiro, sobre a qual se fundou a nascente reflexão dos missionários. Os negros africanos eram os preferidos dos grandes proprietários de terra, que, ao mesmo tempo, sabiam que ainda não poderiam abrir mão dos índios. Por isso, ao criticar a primeira lei que proclamava sua liberdade no Brasil (1570), proibindo entre outras coisas a captura mediante o controvertido sistema dos resgates, os colonos pediram ao rei D. Sebastião que revogasse a legislação e permitisse que com os ameríndios se pudesse respeitar as

\footnotetext{
15 "Alium barbarorum genus mansuetum, sed sensu valde exiguo, qui nonnihil superiores excellere videntur, quandam reipublicae imaginem prae se ferentes, sed nugarum persimiles et leges et cultus gerentes" (Acosta, op. cit., vol. 1, p. 68). Tradução do autor do texto.

16 "Homines barbari iumentis similes" (Acosta, op. cit., vol. 2, p. 368).

${ }^{17}$ Sobre Molina cf. Carlos Alberto de Moura Ribeiro Zeron, Ligne de foi: la Compagnie de Jésus et l'esclavage dans le processus de formation de la société coloniale en Amérique portugaise (XVI ${ }^{e}-X V I I^{e}$ siècles), Paris, Honoré Champion, 2009, pp. 271-294. À bibliografia citata precisa acrescentar pelo menos António Manuel Hespanha, "Luis de Molina e a escravização dos negros", Análise Social, 35 (2001), pp. 937-960.

${ }^{18}$ Stuart Schwartz, Sugar Plantations in the Formation of Brazilian Society. Bahia, 1550-1835, Cambridge, Cambridge University Press, 1985, pp. 65-72 (ed. brasileira: Companhia das Letras, 1988).
} 
mesmas regras que permitiam providenciar escravos na África, pleiteando assim uma equiparação jurídica por baixo. ${ }^{19}$

Inspirada por motivações diferentes embora conciliáveis - a saber, a condenação à escravidão do corpo na terra, a salvação eterna da alma no céu -, esta nova atenção para com índios e negros africanos refletia uma mudança na sociedade colonial brasileira. A partir do final do século XVI, o Atlântico meridional assume uma fisionomia inédita, marcada pelo fenômeno do comércio escravo. ${ }^{20}$ A viagem em condições terríveis a que eram submetidos todos os anos milhares de negros africanos transformava a experiência da navegação no momento de passagem para uma nova identidade, através de uma prova de sofrimento explícita e frequentemente deplorado pela teologia moral. ${ }^{21}$ Diversamente do caso britânico, ainda faz falta um estudo exaustivo sobre a vida dos escravos nos grandes navios que ligavam a costa ocidental da África ao Brasil. ${ }^{22}$ Contudo, a palavra mais inovadora sobre a reciprocidade dos processos implantados pela importação de escravos africanos na América chega exatamente de um livro sobre o caso brasileiro. Continua a se repetir que "as ligações entre as comunidades de escravos no Novo Mundo com suas regiões de proveniência tinham uma única direção". ${ }^{23}$ Todavia, um original volume dedicado à análise dos enredos e das conexões que se criaram entre o Brasil e a África ocidental, propõe uma conclusão oposta a essa, pois o tráfico de seres humanos teria chegado a modificar em profundidade muitos aspectos das várias sociedades interessadas no comércio escravo. ${ }^{24}$ Inicia-se apenas a entrever o impacto da circulação de homens e objetos criada entre as duas costas do Atlântico meridional. A partir dos primeiros dados disponíveis,

${ }^{19}$ A petição dos colonos está referida em uma carta ao rei de 1573, citada por Zeron, op. cit., pp. 327-328.

${ }^{20}$ Luiz Felipe de Alencastro, O trato dos viventes. Formação do Brasil no Atlântico Sul, séculos XVI e XVII, São Paulo, Companhia das Letras, 2000.

${ }^{21}$ Foi o caso do dominicano Tomás de Mercado em um tratado publicado em 1569. Cf. Pedro M. Abellán, "Una moral para comerciantes en el siglo XVI. Significación de la 'Suma' de Fr. Tomás de Mercado en la historia de la teologia moral”, Miscelanea Comillas, 15 (1951), pp. 81-137.

${ }^{22}$ Stephanie E. Smallwood, Saltwater Slavery. A Middle Passage from Africa to American Diaspora, Cambridge MA, London, Harvard University Press, 2007.

${ }_{23}$ "The ties that bound New World slave communities to their place of origin ran only in one direction" (Smallwood, op. cit., p. 6).

${ }^{24}$ José C. Curto, Paul E. Lovejoy (eds.), Enslaving Connections. Changing Cultures of Africa and Brazil during the Era of Slavery, Amherst NY, Humanity Books, 2004. 
percebe-se que a proposta feita pelos colonos da Bahia a D. João III em 1556 não era completamente improvável: por um lado, não se sabe nada da venda eventual de escravos ameríndios em Cabo Verde, que é o que os colonos portugueses propuseram ao rei; por outro, no final do século, registrava-se no reino do Congo a presença de cerca de 500 mamelucos (mestiços livres de ascendência europeia e ameríndia). ${ }^{25}$ Trata-se apenas de um exemplo, mas que convida a meditar sobre o alcance mais geral dos modelos sociais que se impuseram no Brasil da idade moderna e sobre seus impactos na África.

O novo mundo em que se encontraram vivendo índios e negros africanos reduzidos à escravidão era portanto sujeito a uma contínua evolução, determinada também pelos comportamentos adotados por colonos e missionários. Se a realidade foi aquela de uma sociedade cada vez mais mestiça (mamelucos, mulatos, pardos), os limites postos às oportunidades de resgate e de mobilidade foram definidos por uma superposição entre a difusão do princípio de distinção inspirado pelos estatutos de limpeza de sangue e uma legislação brasileira sobre os índios (e em medida menor, sobre os negros africanos), que não tinha nada de incoerente, conforme lembra Beatriz Perrone-Moisés. Tradicionalmente interpretada como oscilante e contraditória, a sucessão de normas régias e provimentos relativos ao enquadramento dos índios no Brasil adquire maior homogeneidade e clareza se considerarmos a diferença que se fazia entre os que aceitavam pacificamente a conversão e a redução nas aldeias regidas pelos jesuítas (indios aldeados), livres na teoria embora permanecessem sob tutela, retribuídos pelo trabalho desenvolvido e também dotados do direito de posse de terra, e aqueles que ao contrário continuavam vivendo no sertão, num estado de infidelidade e em relações hostis com os portugueses (gentios bravios): estes últimos eram aqueles sobre os quais se discutiu durante séculos a respeito da possibilidade de usá-los como escravos, e é sobre essa categoria que vou me concentrar nas páginas que seguem. ${ }^{26}$ Trabalho e conversão foram os dois alicerces de uma legislação que, embora frequentemente desrespeitada, tornou-se o termômetro fiel das ten-

\footnotetext{
${ }^{25}$ Alberto da Costa e Silva, "Africa-Brazil-Africa during the Era of the Slave Trade", In: Curto, Lovejoy (eds.), op. cit., p. 21.

${ }^{26}$ Beatriz Perrone-Moisés, "Índios livres e índios escravos. Os princípios da legislação indigenista do período colonial (séculos XVI a XVIII)", In: Manuela Carneiro da Cunha (ed.), História dos indios no Brasil, São Paulo, Companhia das Letras, 2000, pp. 115-132.
} 
tativas levadas adiante pelos colonos e pelos missionários de plasmar a sociedade. É o que demonstram também as pesquisas mais recentes sobre os debates que acompanharam aquelas leis.

Separar o olhar teórico da concretude dos processos sociais, no estudo da história conectada do papel dos escravos índios e negros africanos na hierarquia dos grupos humanos no mundo português, seria ato arbitrário. Trata-se de um aspecto frequentemente evacuado com excessiva facilidade pelos estudiosos da história social da escravidão no Atlântico meridional. Ao desinteresse ostentado em uma excelente síntese recente da história do tráfico, na qual se reduz toda a história das controvérsias sobre a licitude da escravidão a uma estéril forma de justificação mais ou menos velada, contrapõe-se a riqueza dos estímulos oferecidos por Carlos Alberto de Moura Ribeiro Zeron em um livro consagrado ao estudo das discussões no seio da Companhia de Jesus. ${ }^{27}$ Em geral, os jesuítas acabaram por apoiar um sistema escravista, do qual eles mesmos se tornavam partícipes em seus colégios e nos engenhos de açúcar que possuíam no Brasil. ${ }^{28}$ Contudo, pela complexidade de posições e pela pluralidade de considerações não apenas abstratas sobre as quais se sustentava, o estudo da reflexão jesuíta também ajuda a compreender como a gradual construção de uma hierarquia social dos grupos humanos nas colônias lusitanas, longe de depender somente de razões de oportunidade material, alimentou-se constantemente de juízos de ordem religiosa.

Isso foi ainda mais evidente no caso aqui considerado, o dos escravos índios e africanos cuja condição, afinal, era legitimada pelo objetivo da salvação da alma. Desse modo, para investigar a gênesis e as características de uma dupla discriminação com fortes analogias, no contexto da classificação geral da nova humanidade que teve que viver sob a autoridade política do império português, faz-se antes de tudo necessário retornar ao episódio clamoroso do batismo forçado dos judeus em Portugal (1497), ao equilíbrio social por ele acarretado e seu impacto a médio e longo prazo sobre a cultura oficial lusitana.

${ }^{27}$ Zeron, op. cit. Cf. em particular a introdução. A outra obra a que me refiro é Olivier Pétré-Grenouilleau, Les traites négrières. Essai d'histoire globale, Paris: Gallimard, 2004.

${ }^{28}$ De maneira muito menos precisa e documentada do que Zeron, a esta conclusão havia já chegado Dauril Alden, "Black Robes Versus White Settlers: the Struggle for 'Freedom of the Indians' in Colonial Brazil”, In: Howard Peckham and Charles Gibson (eds.), Attitudes of Colonial Powers Toward the American Indian, Salt Lake City, University of Utah Press, 1969, pp. 27-29. 


\section{Exitos globais do paradigma antijudaico: rastros esparsos de uma teoria.}

No decorrer dos séculos da idade moderna, com uma significativa aceleração entre o final do século XVI e a primeira metade do XVII, ergueu-se no mundo português uma barreira de tipo institucional para impedir uma possível ascensão na hierarquia social de pessoas que não pertencessem à categoria dos brancos europeus, desde sempre de religião católica, chamados cristãos-velhos. ${ }^{29} \mathrm{O}$ instrumento preferido foi aquele dos estatutos de limpeza de sangue, que representavam um patrimônio comum a toda a península ibérica na fase de superação do convívio medieval entre as três religiões (cristã, judaica e muçulmana), substituída por uma uniformidade de religião que acabou dominando a sociedade espanhola e portuguesa ao longo da época das expulsões e das conversões forçadas das minorias (1492-1614). Apoiada na ideia de que os convertidos seriam portadores de uma mácula que se transmitia de geração em geração, tornando inaptos também seus descendentes, elaborou-se uma teoria da honra que levou à discriminação e à exclusão oficial dos cargos públicos, da carreira eclesiástica e de numerosas profissões, qualquer súdito em cujas veias corresse sangue de judeus ou muçulmanos, mas também, já a partir de 1514, de ciganos e ameríndios, e de 1603, de negros e mulatos. Esse processo de naturalização da antiga crença religiosa, transformada no traço qualificador de uma casta (ou raça), resistente ao tempo e à mescla das gerações, representou uma contribuição precoce e original do mundo ibérico, apesar de indireta, para a gênese do racismo moderno. ${ }^{30}$

Em Portugal e no seu império, essas normas de segregação se aplicaram mais tardiamente do que no contexto espanhol e, em parte, isso foi o fruto envenenado daquele processo de hibridação ensejado pela união dinástica entre as duas coroas ibéricas (1580-1640). ${ }^{31}$ Mas se a difusão dos estatutos de pureza pode ser vista como uma reação identitária ao fenômeno da primeira mundialização, cor-

\footnotetext{
${ }^{29}$ Fernanda Olival, "Rigor e interesses: os estatutos de limpeza de sangue em Portugal", Cadernos de Estudos Sefarditas, n. 4, 2004, pp. 151-182.

${ }^{30}$ É uma história que ainda está esperando ser escrita de forma exaustiva. Na vertente lusitana pode-se recorrer, por enquanto, a Maria Luiza Tucci Carneiro, Preconceito Racial em Portugal e Brasil Colônia. Os cristãos-novos e o mito da pureza de sangue, São Paulo, Perspectiva, 2005. Para o caso dos ciganos cf. também Bill M. Donovan, "Changing Perceptions of Social Deviance: Gypsies in Early Modern Portugal and Brazil”, Journal of Social History, no 26, 1992, pp. 33-53.

${ }^{31}$ Serge Gruzinski, Les quatre parties du monde. Histoire d'une mondialisation, Paris, La Martinière, 2004.
} 
roborada pela retomada de um sistema de proteção das elites sociais enraizado na Espanha, não deve ser omitido que na cultura lusitana encontravam-se presentes todos os elementos para uma expansão em escala global do paradigma antijudaico, já difuso na sociedade e nas instituições portuguesas.

A falta de uma teoria orgânica da discriminação e o caráter não homogêneo dos estatutos de exclusão por defeito de sangue são indicadores das resistências que a afirmação de um princípio rígido regulador da criação de uma hierarquia etnográfica e social encontrou em Portugal e que, apesar disso, não se conseguiu conter. Dada a ausência de alternativas reais oferecidas aos judeus, seu batismo em massa sob D. Manuel I é um acontecimento de porte excepcional por suas dimensões e pela sua dinâmica de inaudita violência. ${ }^{32}$ A interpretação teológica do franciscano John Duns Scot, que tinha fornecido uma argumentação para autorizar a solução da conversão forçada, declarando legítima uma ação nesse sentido quando encomendada por um príncipe secular, foi muito criticada durante o século XVI, não somente pelos cristãos-novos (conforme começaram a ser chamados os judeus convertidos), mas também por homens da Igreja e cronistas régios. ${ }^{33}$ Fundada em uma plena aprovação do batismo imposto aos judeus de Espanha pelo rei visigodo Sisebuto no século VII (contra a tradição do direito canônico, que louvava sua boa vontade, mas condenava o gesto), a doutrina de Scot se insinuou até nas dobras da reflexão missionária, paralelamente à sua consagração pelo maior teólogo do reino, o dominicano Martin de Ledesma, discípulo de Francisco de Vitoria e lente de Prima da Universidade de Coimbra. ${ }^{34}$

O modelo do batismo dos judeus em Portugal refletia uma noção da conversão como passagem abrupta para a religião cristã, sancionada mediante um rito considerado válido, mesmo se ministrado sem prévia catequese nem consentimento por parte do recebedor. Nesse exemplo, repetido muitas vezes no império, desde as cerimônias coletivas no Brasil até as liturgias solenes em Goa, estava contido o germe da discriminação futura: as próprias modalidades de aplicação do

\footnotetext{
${ }^{32}$ François Soyer, The Persecution of the Jews and Muslims of Portugal. King Manuel I and the End of Religious Tolerance (1496-7), Leiden, Boston, Brill, 2007.

${ }^{33}$ Sobre o assunto, permito-me apontar para Giuseppe Marcocci, “....per capillos adductos ad pillam' Il dibattito cinquecentesco sulla validità del battesimo forzato degli ebrei in Portogallo (1496-1497)", In: Adriano Prosperi (org.), Salvezza delle anime, disciplina dei corpi. Un seminario sulla storia del battesimo, Pisa, Edizioni della Normale, 2006, pp. 339-423.

${ }^{34}$ Sobre a opinião a respeito do assunto por parte de Ledesma no comentário teológico impresso entre 1555 e 1560, cf. Marcocci, op. cit., pp. 389-391.
} 
sacramento jogavam uma sombra sobre a possibilidade de uma adesão sincera à nova fé pelos neófitos. A relevância das consequências daquele modelo era tal que a teoria que lhe era subentendida foi um dos nós enfrentados pelo jesuíta Manuel da Nóbrega no Diálogo sobre a conversão do gentio (1556-1557), um dos primeiros textos a debater os problemas concretos da evangelização no Império português.

"Não foi boom fazer el-Rei Dom Manoel os judeus christãos", objetava Nóbrega em relação aos índios que eram "christãos por força, e gentios na vida e nos custumes e vontade". A distância das ideias de Scot se tornava explícita com o aceno ao exagero do rei Sisebuto:

GONÇALO ALVAREZ: [...] E el-Rei Sesebuto, Rei d'Aragão, não se lhe condena nos sagrados canones o zelo com que contra vontade dos pais, judeus, mandou en seu reino bautizar seus filhos, mas o fim não lho louvão. Logo nem tudo o que parece bem se á-de fazer, senão o que realmente for boom. ${ }^{35}$

Nóbrega opinava sobre matéria incandescente. De fato, quem tentava se retratar daquele tipo de batismo era considerado apóstata, ficando exposto às severas penas da justiça eclesiástica. Aquele rito devia representar uma cisão nítida com o passado, sancionada pela eliminação de qualquer rastro exterior da antiga religião. Por isso, a referência ao batismo forçado dos judeus acabou assumindo um valor específico também no âmbito missionário, desenhando afinal um ideal de sociedade na qual não era admitido nenhum aspecto que lembrasse que aquela pessoa pertencera a cultos diversos do cristão. Consequentemente, uma contínua suspeita acompanhava a figura do convertido, simplesmente por ser convertido, o que favorecia sua subalternidade na hierarquia social. A Índia nos forneceu uma confirmação do caráter global assumido pelo paradigma antijudaico. Em 1579, uma junta de missionários e teólogos presidida pelo arcebispo eleito de Goa, D. Henrique de Távora, rechaçou o pedido de alguns hindus de Salsete que queriam praticar em público "ritos gentílicos e ceremonias", expondo, entre outros, o seguinte argumento:

Em Hespanha e Portugal despois que os catholicos reis Dom Fernando e Dona Isabel e o nosso rey Dom Manuel com tanta honra da fee e sua desterrarão de seus reinos os mouros e judeos com as suas mesquitas e synagogas desfeitas, nunqua por elles mais, nem por seus successores nos reinos e zelo da fee, foi permittido, ou pera milhor

${ }^{35}$ Manuel da Nóbrega, “Diálogo sobre a conversão do gentio”, In: Id., Cartas do Brasil e mais escritos, ed. Serafim Leite, Coimbra, Imprensa da Universidade de Coimbra, 1955, doc. 27, p. 231. 
dizer concedido, que os mouros e judeos tornassem a ter synagogas, ou mesquitas, nem usassem de suas sacrilegas ceremonias e superstições $[\ldots] .^{36}$

Pela insistência sobre as resoluções contra os judeus (e os muçulmanos) na península ibérica no fim do século XV, pode-se compreender também porque Acosta, no trecho de De procuranda Indorum salute acima citado, colocou índios e negros africanos na mesma linha cronológica da história das conversões, em cujo início se encontram exatamente os judeus.

O paradigma antijudaico ensejado pelo batismo forçado e alimentado pela retórica da limpeza de sangue, que estava em vias de afirmação no resto da península ibérica, desde meados do século XV, ofereceu um modelo e um quadro jurídico de referência (incluindo a tradição antijudaica do direito canônico medieval, que foi retomada, por exemplo, nas controvérsias sobre os casamentos mistos) pela extensão do princípio de discriminação que moldava a hierarquia humana no mundo português. Ainda assim, restava uma distância irreparável entre a condição social e civil dos cristãos-novos e aquela de índios e negros africanos reduzidos à escravidão.

No império português que, desde as bulas papais de meados do século XV, encontrara sua legitimação na missão de apostolado universal, a conversão tinha a função política de regulamentar a entrada de novos súditos em uma comunidade distinta dos que perseveravam no estado de infidelidade, embora esta comunidade também tenha logo sido discriminada em relação aos colonos europeus.

Um exame comparativo rápido das estratégias adotadas em relação aos diversos grupos de convertidos permite decifrar, de forma empírica, alguns nós implícitos em um modelo de ordem social que, desde meados do século XVI, foi-se definindo a partir de uma cultura que colocava lado a lado "herege, gentio, judio, mouro", citando o que se podia ler no frontispício de um tratado de apologética daquela época. ${ }^{37} \mathrm{O}$ batismo forçado dos judeus em Portugal foi acompanhado pela promessa de uma equiparação jurídica entre cristãos-novos e cristãos-ve-

\footnotetext{
${ }^{36}$ Cópia do assento que se tomou em 9 de Abril de 1579, In: Collecção de resoluções e pareceres de matérias canónicas e morães, Biblioteca Pública de Évora [BPE], cod. CXXII/2-11 d, f. 23.

${ }^{37}$ João Soares, Libro dela verdad d'la fe. Sin el cual no deve estar ningun xpiano, Lisboa, por Luis Rodriguez, 1543. Outro caso parecido foi aquele da obra de Diogo de Sá, Inquisiçam e segredos da Fee contra a obstinada perfidia dos Iudeus \& contra Gentios \& Hereges (ca. 1563-1564), cuja públicação porém não foi autorizada e até hoje está guardada manuscrita no Arquivo Nacional da Torre do Tombo [ANTT], Conselho Geral do Santo Ofício [CGSO], liv. 175.
} 
lhos, desrespeitada primeiramente nos fatos e depois também no plano normativo (até 1773, quando o Marquês de Pombal decretou a abolição de qualquer distinção). Reforçada por uma incessante perseguição por parte da Inquisição aos cristãos-novos, acusados de cripto-judaísmo, a discriminação dos judeus convertidos e de seus descendentes, antes de se cristalizar nos estatutos de pureza que impediram seu acesso a cargos públicos, ordens religiosas e militares, profissões e ensino universitário, traduziu-se em uma extensa tentativa de limitar sua liberdade de movimento, proibindo ora que saíssem do reino sem prévia licença, ora que circulassem nos territórios do império, ora até que se afassem da localidade de residência nos meses anteriores e subsequentes a uma visita da Inquisição. ${ }^{38}$ Tratava-se, com toda evidência, de medidas voltadas a atingir um setor da população lusitana que, tanto no reino quanto no império, podia alcançar os patamares mais altos da hierarquia social (banqueiros, financistas, grandes mercadores), e que tinha representantes em todos os níveis, até nas camadas mais humildes (artesãos, vendedores ambulantes, camponeses). Foi exatamente pela onipresença dos cristãos-novos que se chegou a lançar um alarme geral, apontando-os como uma ameaça à integridade da identidade lusitana e, na primeira metade do século XVII, chegou-se até a propor sua expulsão do reino. ${ }^{39}$ Em geral, a capacidade demonstrada repetidas vezes de pôr um freio tanto à Inquisição como à legislação discriminatória e segregacionista, assim como de contornar as proibições impostas pelos estatutos, revelava-se como uma evidente confirmação do risco de uma ascensão endêmica dos cristãos-novos. Fé e honra social encontraram assim razões válidas para uma sólida aliança contra os descendentes dos judeus, aliança que visava preservar o ideal de uma ortodoxia católica íntegra, de um lado; e a posição de vantagem de quem pertencia à maioria da sociedade, do outro. ${ }^{40}$

\footnotetext{
${ }^{38}$ Para uma cronologia de tais limitações cf. Carneiro, op. cit., pp. 47-148. Sobre as tentativas de controle da mobilidade dos cristãos-novos até os limites do mundo lusitano, permito-me remeter para as fontes discutidas em meu livro I custodi dellortodossia. Inquisizione e Chiesa nel Portogallo del Cinquecento, Roma, Edizioni di Storia e Letteratura, 2004, pp. 338-343.

${ }^{39}$ Para um panorama geral dos tratados em que foram formuladas estas propostas cfr, Bruno Feitler, "O catolicismo como ideal. Produção literária antijudaica no mundo português da Idade Moderna", Novos Estudos, n. 77, 2005, pp. 137-158.

${ }^{40}$ Percebe-se a necessidade de uma reconstrução da história religiosa, social e cultural dos cristãosnovos no mundo lusitano da idade moderna. Por enquanto, continua válido o estudo clássico de João Lúcio de Azevedo, História dos Christãos novos portugueses, Lisboa, A.M. Teixeira, 1921.
} 
O modelo que foi se elaborando para os cristãos-novos encontrou aplicação também no caso da minoria muito mais exígua dos mouriscos, aqueles muçulmanos que chegaram a Portugal e foram batizados após a expulsão de $1496 .{ }^{41} \mathrm{Se}$ no caso desses últimos se percebe uma influência da legislação espanhola sobre os mouriscos (principalmente durante a união dinástica das duas coroas ibéricas), o exemplo seguido pela madre pátria com os cristãos-novos teve uma direta retomada na Índia. Primeira a chamar a atenção para este fato, Ângela Barreto Xavier, em seu ensaio seminal, concentra seu olhar sobre a legislação em vigor em Goa relativa aos convertidos. ${ }^{42}$ De fato, foi em Goa que surgiu a primeira norma imperial de que se tem conhecimento, voltada a excluir os convertidos dos ofícios públicos (1519). ${ }^{43}$ Provavelmente, o significado mais autêntico do sonho frequentemente almejado e nunca realizado de constituir em Goa "um outro Portugal" correspondia ao desejo de recriar na Índia um tipo de sociedade uniforme no plano confessional, mas caracterizada por normas de discriminação e segregação para quem não cabia na categoria de cristão-velho. ${ }^{44}$

Pertencentes à primeira classe de bárbaros, segundo a classificação de Acosta, os indianos deveriam ter sido conquistados pela fé cristã por meio da persuasão ("se nos empenhamos em sometê-los a Cristo por força e poder, não vamos conseguir mais que apartá-los totalmente da lei cristâ"). ${ }^{45}$ Mas aquele modelo nunca chegou a ser realmente aplicado. Nem mesmo depois da promulgação de um decreto, em 1542, no qual se estabelecia a equiparação jurídica entre todos os habitantes cristãos de Goa "asy portugueses, como de qualquer outra nação, geração e calidade”. Seguidamente àquele decreto (estendido para toda a Índia em 1571), a conversão tornou-se um ritual de passagem que transformava "os novos novos-cristãos numa espécie de... 'portugueses". ${ }^{46}$ Mas apesar da aparente

${ }^{41}$ Para uma introdução geral cf. Ahmed Boucharb, Os pseudo-mouriscos de Portugal no séc. XVI: estudo de uma especificidade a partir das fontes inquisitoriais, Lisboa, Hugin, 2004.

${ }^{42}$ Ângela Barreto Xavier, "De converso a novamente convertido. Identidade política e alteridade no Reino e no Império", Cultura. Revista de Teoria e História das Ideias, n. 22, 2006, pp. 245-275.

${ }^{43}$ Arquivo Portuguez Oriental [APO], ed. Joaquim Heliodoro da Cunha, New Dehli, Asian Educational Services, 1992, vol. 2, doc. 18.

${ }^{44}$ Aprofundei esse aspecto em meu artigo "Costruire un outro Portugal. Strategie di conversione a Goa fra Cinque e Seicento", Rivista di Storia del Cristianesimo, n. 7, 2010, pp. 23-34.

${ }^{45}$ Acosta, op. cit., vol. 1, p. 62.

${ }^{46}$ Ângela Barreto Xavier, “'Aparejo y disposición para se reformar y criar otro nuevo mundo’. A evangelização dos indianos e a política imperial joanina”, In: D. João III e o Império. Actas do Congresso Internacional, Lisboa, CHAM, 2004, pp. 783-805: 795. O decreto pode-se ler em APO, vol. 2, doc. 30. 
analogia sobre a qual insiste Barreto Xavier, aquela norma nada tinha a ver com o antigo direito romano que concedia a civitas a todo súdito do império, prescindindo de sua religião. ${ }^{47}$ Justamente aquele ideal de inclusão estava então sendo criticado no reino, onde, graças a uma precoce leitura e interpretação em chave cristã de Maquiavel, houve uma tentativa de favorecer uma abordagem menos fechada em relação a convertidos e infiéis das colônias lusitanas. ${ }^{48} \mathrm{Na}$ realidade, o decreto de 1542 não remetia a nenhuma abertura de cunho universalista, pois reproduzia de perto a legislação emanada, desde 1497, em Portugal, no caso dos cristãos-novos e visava, assim como outras medidas que se seguiram a ele, tornar a conversão vantajosa para hindus e muçulmanos, quando comparada com a permanência no estado de infidelidade. As polêmicas sobre os solenes batismos em massa e a intensa perseguição inquisitorial em Goa, que tinha entre os indianos suas vítimas mais frequentes (tanto que foi necessária uma derrogação à norma que previa a pena de morte para os relapsos) demonstram como o espírito daquele decreto foi constantemente traído, embora os estatutos de limpeza tenham tido muito menos espaço na Índia do que em Portugal. ${ }^{49}$ Não foi por acaso, portanto, que a obsessão pela pureza por parte das autoridades lusitanas levou os inquisidores de Goa a pedir que não se permitisse a entrada na colônia indiana de nenhum europeu que não fosse ibérico. ${ }^{50}$

Por um lado o princípio de uma superioridade baseada no sangue garantiu aos cristãos-velhos uma posição de privilégio e de superioridade na hierarquia social, em relação a possíveis concorrentes no reino e no império, como os cristãos-novos ou os neófitos de origem indiana; por outro teorias e estratégias de discriminação mudavam profundamente diante de grupos humanos cuja subalternidade nunca

${ }^{47} \mathrm{O}$ assunto encontra-se desenvolvido mais extensamente em Ângela Barreto Xavier, $A$ invenção de Goa. Poder imperial e conversões culturais nos séculos XVI e XVII, Lisboa, ICS, 2008, pp. 37-80.

${ }^{48}$ Aprofundei a questão em meu artigo "Machiavelli, la religione dei romani e l'impero portoghese", Storica, n. 41-42, 2008, pp. 35-68.

${ }^{49}$ Por outro lado, já revia o alcance do decreto de 1542 Charles R. Boxer, Relações raciais no Império português, 1415-1825, Porto, Afrontamento, 1988, pp. 70-72 (ed. or. Oxford, 1963). Sobre a faculdade de absolver os relapsos, concedida à Congregação romana do Santo Ofício em 1599, permito-me remeter ao meu ensaio "La salvezza dei condannati a morte. Giustizia, conversioni e sacramenti in Portogallo e nel suo impero. 1450-1700 ca., In: Adriano Prosperi (org.), Misericordie. Conversioni sotto il patibolo tra Medioevo ed età moderna, Pisa, Edizioni della Normale, 2007, pp. 189-255: 199-200.

50 "He couza mui importante á pureza e á conservação da fee nom passar cá nenhum estrangeiro" (carta para o inquisidor geral D. Henrique, 23 de Dezembro de 1562, In: António Baião, A Inquisição de Goa, Lisboa, Academia das Ciências, 1930-1945, vol. 1, p. 41). 
esteve em discussão, como os índios e os negros africanos. Tal como a acusação de descender do povo deicida pesava sobre os cristãos-novos, para os quais, por exemplo, durante muito tempo era negada a eucaristia em caso de pena de morte, assim a inferioridade social de africanos e ameríndios encontrava confirmação na invenção de mitos e lendas, a saber, a maldição dos descendentes de Caim, no caso dos primeiros, e a atribuição de um feroz canibalismo endêmico, em uma permanente violação da lei natural para os segundos. ${ }^{51}$ Era um assunto a mais, diferente tanto da discussão sobre sua plena natureza humana, concedida quase imediatamente a ambos os grupos (pelo cronista régio Gomes Eanes da Zurara aos primeiros negros africanos capturados pelos portugueses e por Nóbrega aos índios brasileiros), quanto do mutável juízo dos missionários, ligado antes de mais nada à capacidade de conversão. Em meados do século XVI, por exemplo, o jesuíta Henrique Henriques elogiou os resultados alcançados na América "onde ouço dizer que [...] são milhores christãos commummente que os destas partes da India" (opinião que com certeza Acosta não compartilharia). ${ }^{52}$

Além de levar em consideração o respectivo peso social ao refletirmos menos genericamente sobre a contribuição do paradigma antijudaico na formação de uma "escala dos povos" dentro do mundo lusitano e ibérico em geral, não devemos esquecer que, mesmo para além das teorias de justificação da redução à escravidão, o enquadramento social dos negros africanos remonta a décadas anteriores à grande fratura do batismo forçado dos judeus. Diferentemente do secular inimigo muçulmano enfrentado no Norte da África, para os negros da

${ }^{51}$ Contra a comunhão negada aos novos cristãos falou o importante jurista António da Gama (cf. meu artigo "La salvezza dei condannati a morte", pp. 228-229). Sobre o assunto da maldição dos descendentes de Cam e sua origem portuguesa, cf. Benjamin Braude, "The Sons of Noah and the Construction of Ethnic and Geographical Identities in the Medieval and Early Modern Periods", William and Mary Quarterly, n. 54, 1997, pp. 103-142. Sobre a antropofagia cf. obra Frank Lestringant, Le Cannibale. Grandeur et décadence, Paris, Perrin, 1994.

${ }^{52}$ O juízo de Henriques se encontra em uma carta sua para o geral Diego Laínez, 19-20 de dezembro de 1558, In: Documenta Indica, ed. Josef Wicki, Roma, Monumenta historica Soc. Iesu, 1956, vol. 4. doc. 22. Sobre os negros africanos, em meados do século XV, o cronista Zurara escreveu que pertenciam à "geração dos filhos de Adão" (Crónica de Guiné, ed. José de Bragança, Porto, Livraria Civilização, 1973, p. 122). Sobre a posição defendida por Nóbrega em Diálogo sobre a conversão do gentio, intervindo na questão da humanidade dos índios, cf. Fred Gillette Sturm, "Estes têm alma como nós?': Manuel da Nóbrega’s view of the Brazilian Indios", In: Alfred Hower, Richard A. Preto-Rodas (eds.), Empire in Transition. The Portuguese World in the Time of Camões, Gainesville, University of Florida Press, 1985, pp. 72-82. Nóbrega, contudo, defendeu a ideia de uma "humanidade incompleta" dos índios, sendo necessário não tanto reduzi-los à escravidão, mas mantê-los sob tutela (Zeron, op. cit., pp. 138-139). 
Senegâmbia, entendeu-se oferecer a perspectiva da conversão, conforme demonstra a controvérsia surgida no início do século XVI sobre a falta de batismo dos escravos que desembarcavam em Lisboa. ${ }^{53}$ Aquela era uma época em que os confins ainda eram móveis: eloquentemente o confirma a história da confraria mista de Nossa Senhora do Rosário, onde se achavam, lado a lado, brancos portugueses e negros africanos, antes de, em meados do século, a oposição dos donos de escravos ao privilégio de emancipação de que gozava aquela singular irmandade, decretasse o fim de uma experiência de convivência inédita no mundo ibérico da idade moderna, além de abertamente contrastar com a discriminação que naqueles anos afligia os cristãos-novos. ${ }^{54}$

Um último aspecto mantinha africanos e índios separados dos descendentes dos judeus: embora os rituais que caracterizavam a apostasia dos primeiros fossem frequentemente definidos como diabólicos, não se temia que pudessem representar uma ameaça real de contágio; muito pelo contrário, as práticas cripto-judaicas eram consideradas uma ameaça que, segundo um difuso preconceito, poderia contaminar em profundidade a pureza do catolicismo lusitano, graças à presumida habilidade dos cristãos-novos de se insinuar em todos os níveis da sociedade por meio de oportunas estratégias matrimoniais e carreiras protegidas. Certamente não faltaram exemplos da atração potencial entre os colonos brancos por alguns rituais e liturgias dos povos extraeuropeus (sobre tudo os africanos, seja no continente de origem, seja no Brasil) $;{ }^{55}$ contudo, mais uma vez, os úni-

\footnotetext{
${ }^{53}$ Prova disso é a existência de uma série de bulas papais e provimentos legislativos entre 1513 e 1516; o mais importante entre eles foi a norma inserida, em 1514, nas Ordenações Manuelinas, liv. 5 , tít. 99, que impôs maior vigilância sobre a administração do batismo aos escravos.

${ }^{54}$ Contudo, eu não concordo com Didier Lahon quando, no importante ensaio "Black Africans slaves and freedmen in Portugal during the Renaissance: creating a new pattern of reality", In: Kate P. J. Lowe, Thomas F. Earle (eds.), Black Africans in Renaissance Europe, Cambridge, Cambridge University Press, 2005, pp. 273-274, escreve que os acontecimentos em torno da confraria foram influenciados pela política régia relativa aos cristãos-novos.

${ }^{55}$ Um exemplo da precoce atração pelos cultos locais em uso entre os negros da África ocidental por uma comunidade de cristãos-novos portugueses fugidos da ilha de Santiago, no arquipélago de Cabo Verde, para a terra firme, é apontado por Adelino Teixeira da Mota, Alguns aspectos da colonização e do comércio marítimo dos portugueses na África ocidental nos séculos XV e XVI, Lisboa, Junta de Investigações Científicas do Ultramar, 1976, p. 15. E a respeito do Brasil cf. James H. Sweet, “'Not a Thing for White Men to See': Central African Divination in Seventeenth-Century Brazil", In: Curto, Lovejoy (eds.), op. cit., pp. 139-148. Para um quadro geral remeto a Laura de Mello e Souza, O diabo e a Terra de Santa Cruz. Feitiçaria e religiosidade popular no Brasil colonial, São Paulo, Companhia das Letras, 1986.
} 
cos que se encontraram em condição de, pelo menos em parte, ser comparados com a dos cristãos-novos eram os indianos convertidos. Embora os cultos hindus fossem também classificados como idólatras e diabólicos por missionários e teólogos, não foram raros os casos de portugueses acusados pela Inquisição de Goa de terem aderido às crenças locais principalmente para tirar proveito de artes divinatórias, de modo que, no final do século XVI, até mesmo um governador geral e seu entourage chegaram a ser acusados de envolvimento com esses cultos. ${ }^{56}$ Desse ponto de vista, a aparente "incomunicabilidade" entre índios e colonos (com a relevante exceção dos portugueses que não ficaram indiferentes ao movimento de revolta da "santidade de Jaguaripe", dos anos 1580), representa talvez um outro elemento a ser levado em consideração para dar conta do fato de ter sido o único grupo de convertidos que permaneceu isento da jurisdição inquisitorial no Império lusitano. ${ }^{57}$

\section{Tempo de salvação: uma cronologia conectada}

A razão declarada para se isentar os índios brasileiros do tribunal da fé, delegando a competência sobre seus erros ao bispo da Bahia e aos padres jesuítas (que já exerciam uma autoridade exclusiva sobre os índios aldeados), foi a de mitigar a justiça aplicada aos convertidos apóstatas "para que não se intimidem os outros" ${ }^{58}$ Escolha esta diretamente ligada à consciência da peculiar fraqueza das convicções religiosas dos índios, acompanhada também por uma preocupação mais objetiva e intensa pela sua salvação. ${ }^{59}$ Deparamo-nos aqui com um nó

${ }^{56}$ Ver Baião, op. cit., vol. 1, p. 317-318.

${ }^{57}$ Sobre o episódio de Jaguaripe, cf. Ronaldo Vainfas, A heresia dos índios. Catolicismo e rebeldia no Brasil colonial, São Paulo, Companhia das Letras, 1997. Uma interpretação diferente em Alida C. Metcalf, "Millenarian Slaves? The Santidade de Jaguaripe and Slave Resistance", The American Historical Review, 104 (1999), pp. 1531-1559. Casos de vigilância inquisitorial sobre índios e negros africanos são apontados por James E. Wadsworth, "Jurema and Batuque: Indians, Africans and the Inquisition in Colonial Northeastern Brazil", History of Religions, n. 46/2, 2006, pp. 140-162. Atribuía-se a estes últimos a responsabilidade da corrupção moral e sexual dos colonos europeus: cf. Ronaldo Vainfas, Trópico dos pecados. Moral, sexualidade e Inquisição no Brasil, Rio de Janeiro, Campus, 1989.

${ }^{58}$ Provisão de 12 de Fevereiro de 1579, In: Isaías da Rosa Pereira, Documentos para a história da Inquisição em Portugal, século XVI, Lisboa, Cáritas Portuguesa, 1987, doc. 52.

${ }^{59}$ A questão da salvação dos índios brasileiros foi objeto de um estudo recente por Stuart Schwartz, All Can Be Saved. Religious Tolerance and Salvation in the Iberian Atlantic World, New Haven and London, Yale University Press, 2008, pp. 177-206 (ed. brasileira: Companhia das Letras/ EdUSC, 2009). Sua abordagem é diferente daquela proposta nas páginas seguintes. 
decisivo dos fundamentos teóricos do modelo de discriminação que caracterizou o mundo português acompanhado do maciço recurso ao trabalho forçado de escravos índios e africanos. Para além da exploração dos corpos e do preconceito antijudaico, a teologia também teve um papel importante na determinação das hierarquias existentes entre os escravos. No decorrer do tempo, registram-se vozes em defesa de uma geral superioridade dos índios, como aquela do jesuíta Fernando Pérez, que nas últimas décadas do século XVI definiu os negros africanos como "muito mais rudes que os índios", ou, um século depois, a opinião do governador do Maranhão que achava que o serviço de um escravo índio valia mais do que o de dois africanos..$^{60}$ Baseadas em considerações de ordem antropológica e prática, tais posições foram contudo raras e minoritárias. ${ }^{61}$

O que se impôs na verdade foi a imagem de uma relativa superioridade dos negros africanos, mais cobiçados e procurados por senhores de engenho e, em geral, por colonos e missionários. A própria casuística que orientava a ação desses últimos acabou fornecendo provas incontestáveis que atribuíam aos africanos maior predisposição para a vida cristã. Numa listagem de dúvidas sobre o Brasil, produzida em ambiente jesuíta no final do século XVI, foi levantada a questão de saber se era oportuno conceder a comunhão aos índios neófitos, sabendo que "são inconstantissimos" e que "os da Guine são de milhor juizo e entendimento e os prelados não lho dão por ser gente que se embebedão e andão amancebados". ${ }^{62}$ Opiniões importantes, visto que, diferentemente do que se possa pensar, na época, ainda não havia sido elaborada nenhuma estratégia específica de conversão para os negros africanos. Fazia mais de meio século que o debate sobre os direitos dos índios ia de par com outro no qual se questionava se tinham as faculdades intelectuais necessárias para alcançar a salvação. Não se deve excluir que a

\footnotetext{
60 "Si aethiopes eiusmodi multo magis quam indi rudes sint, eo magis de eis timendum est ut inter infideles a fide retrocedant quo minore naturali lumine iudicioque pollent quo fide complectantur", In: "Circa Indorum matrimonia aliquorum Patrum Sententiae", In: BPE, cod. CXVI/1-33, f. 104. Sobre as circunstâncias desta consulta, datada de 1583, cf. Zeron, op. cit., p. 164. A carta, enviada pelo Govvernador Gomes Freire de Andrade ao rei D. Pedro II em 1686 é citada por Alden, "Indian versus Black Slavery", p. 79.

${ }^{61}$ Sublinho aqui apenas de passagem que no século XVII difundiu-se sempre mais a discussão sobre a teoria judeo-genética dos ameríndios, que oferecia uma visão negativa dos mesmos. Cf. Giuliano Gliozzi, Adamo e il Nuovo Mondo. La nascita dell'antropologia come ideologia coloniale: dalle genealogie bibliche alle teorie razziali, Firenze, La Nuova Italia, 1977, pp. 49-111.

62 "Alguãs duvidas que se offerecem nas missõis", In: BPE, cod. CXVI/1-33, f. 160.
} 
representação dos escravos africanos como mais mansos e dispostos a suportar pesadas cargas de trabalho, ao contrário dos índios, conotados como ferozes e rebeldes, tenha favorecido um longo silêncio sobre seu destino eterno para evitar repercussões sobre a ordem cultural e social que garantia sua plena sujeição (lembremos que segundo a legislação sobre os indígenas brasileiros, certamente oscilante, mas bastante linear nesse ponto, podiam ser reduzidos à escravidão somente os índios inimigos, ou seja, aqueles que viviam no sertão, aos quais se atribuia uma atitude de resistência radical aos dominadores europeus).$^{63}$

Envolvidos, desde meados do século XV, no processo da expansão colonial portuguesa, os negros africanos foram logo privados do dominium e reduzidos à escravidão em nome da esperança de uma futura conversão, segundo o que foi estabelecido pela bula Dum diversas (1452), retomada três anos depois pela Romanus Pontifex. ${ }^{64}$ Tratou-se de uma teoria que durante séculos não sofreu modificações. Ao contrário, no caso dos ameríndios, a Igreja assumiu uma posição oficial oposta, mediante a bula Veritas ipsa (1537), que proclamava sua plena humanidade (veri homines) e condenava sua redução à escravidão.$^{65} \mathrm{~A}$ constituição apostólica de Paulo III interveio em um momento de intenso debate sobre a natureza e os direitos dos índios da América espanhola. Somente dois anos depois o dominicano Francisco de Vitoria, principal professor de teologia da Universidade de Salamanca, pronunciaria as célebres relectiones De Indis. ${ }^{66} \mathrm{Da}$

\footnotetext{
${ }^{63}$ A hostilidade em relação aos índios do sertão aparece claramente em posicionamentos como aqueles do jesuíta Inácio de Tolosa, que foi durante muito tempo missionário no Brasil: "Os jndios que vem do sertão a visitar seus parentes que residem antre os portugueses com proposito de se tornar outra vez entre gentios, em nenhuma maneira devem ser baptizados pelo perigo çerto que ay de ficarse com so o nome de christão e obra de gentio", em "O que se offeresce açerca dos baptismos dos jndios he o seguinte”, In: BPE, cod. CXVI/1-33, f. 174v. tal posicionamento mudará somente no final do século XVII, quando da emanação de normas favoráveis aos aldeamentos no sertão (Perrone-Moisés, op. cit., p. 119).

${ }^{64}$ Sobre os dois documentos existem importantes apontamentos em artigos como nos de Anthony John R. Russell-Wood, "Iberian Expansion and the Issue of Black Slavery: Changing Portuguese Attitudes, 1440-1770", The American Historical Review, 83 (1978), pp. 23-28 e James H. Sweet, “The Iberian Roots of American Racist Thought", William and Mary Quarterly, n. 54, 1997, pp. 157-158. Ambos, porém, limitam-se a remeter a interpretação das bulas para a teoria da guerra justa. Para um exame mais minucioso, permito-me remeter a minha tese de doutorado La coscienza di un impero. Politica, teologia e diritto nel Portogallo del Cinquecento, Pisa, Scuola Normale Superiore, 2008, pp. 8-20.

${ }^{65}$ Pode-se ler a bula em America Pontificia primi saeculi evangelizationis, 1493-1592. Documenta pontificia ex registris et minutis praesertim in Archivo Secreto Vaticano existentibus, ed. Josef Metzler, Città del Vaticano, Libreria Editrice Vaticana, 1991, doc. 84.

${ }^{66}$ Para uma análise da famosa intervenção de Vitoria, sugiro Pagden, op. cit., pp. 64-108.
} 
leitura de sua correspondência nota-se, porém, como o teólogo que se atrevia a escrever que os índios deviam ser tratados como "naturais de Sevilla", evitava ao mesmo tempo fazer qualquer crítica ao nascente comércio de escravos africanos, alegando tratar-se de um negócio de competência do rei de Portugal. ${ }^{67}$ Ainda que as Leyes nuevas, promulgadas em 1542 por Carlos V, tenham modificado profundamente o sistema da encomienda, limitando a possibilidade de exploração dos índios, não desapareceu a hipótese de um emprego legítimo de escravos nas plantações americanas, transferido para os negros africanos. Esta linha foi sustentada também por Bartolomé de las Casas, que reformou suas posições só muito mais tarde, na Historia de las Indias (lib. 1, cap. 17-27), composta em meados do século XVI, mas que ficou inédita até o século XIX. Discípulo de Vitoria, o teólogo dominicano Domingo de Soto foi o primeiro que escreveu contra o comércio dos negros africanos, atacando, em seu De iustitia et iure (1553-1554) não tanto a escravidão em si, ou a prática do comércio de homens, mas o comportamento dos traficantes lusitanos na costa da África ocidental, negociando "com fraude e engano" (fraude et dolo). ${ }^{68}$

A denúncia da condição de escravização dos ameríndios estimulou uma rica literatura sobre os métodos para se favorecer sua conversão e abrir-lhes as portas da salvação, que culminou no tratado de Acosta. O mundo português permaneceu por longo tempo insensível àquela reflexão prevalentemente teológica e jurídica sobre o tratamento reservado tanto aos índios brasileiros, como aos negros africanos. Mesmo quando se chegou a formas de condenação da arbitrariedade da redução dos índios à escravidão, em nome de sua plena humanidade e no respeito das possibilidades previstas no direito das gentes, elas demoraram a refletir no caso dos africanos, para os quais se continuou a impor uma dura exploração sem nenhuma preocupação com sua alma. Abre-se aqui um campo de investigação ainda pouco explorado.

O passo em que Soto levantava suspeitas sobre a conduta dos portugueses na África foi retomado ao pé da letra pelo confrade Ledesma, lente de teologia

${ }^{67} \mathrm{O}$ juízo sobre os índios é expresso em uma carta para o padre Arcos, de novembro de 1534, publicada em Francisco de Vitoria, "Relectio de Indis", Madrid, CSIC, 1967, p. 138. A carta para Frei Bernardino de Vique de 18 de março de 1546 [há duvidas quanto ao ano] sobre o comércio dos negros africanos pode-se ler em Vicente Beltrán de Heredía, "Colección de dictamenes inéditos del maestro Fray Francisco de Vitoria”, Ciencia tomista, n. 43, 1931, pp. 173-175.

${ }^{68}$ Cito da $2^{\text {a }}$ ed.: Domingo de Soto, De iustitia et iure libri decem, Salmanticae: excudebat Andreas a Portonarijs, 1556, p. 289. 
em Coimbra, na edição impressa de seus comentários (1560), mas nessa atitude não se pode ler mais do que uma parcial concessão a uma genérica condenação moral em troca da manutenção do comércio, posto sob acusação em 1555 pelo ex-dominicano Fernando Oliveira no fervoroso trecho de seu tratado em que acusava os portugueses de serem

os inventores de tam mao trato, nunca usado, nem ouvido antre humanos. Nem se achará, nem rezam humana consinte, que jamays ouvesse no mundo trato pubrico e livre de comprar e vender homens livres e pacificos, como quem compra e vende alimarias, boys ou cavallos e semelhantes. ${ }^{69}$

Escrita numa linguagem apaixonada, mas fundada nos argumentos da teologia escolástica, essa reivindicação da plena humanidade dos negros africanos talvez origine-se na polêmica que na época fervilhava em Lisboa acerca do futuro da irmandade do Rosário e o privilégio de se conceder a liberdade aos associados escravos convertidos. ${ }^{70}$

Na cultura lusitana, contudo, a questão da salvação dos negros africanos continuou sendo contornada. Em 1556, numa consulta sobre a guerra justa preparada para a Mesa da Consciência, em vista da elaboração do regimento para o novo governador do Brasil, Mem de Sá, obra talvez do teólogo da corte Antônio Pinheiro, foram defendidos com firmeza os direitos dos índios do Brasil (partindo não de Vitoria, mas da interpretação do teólogo dominicano Tommaso de Vio, mais conhecido como Cardeal Caietano): nenhum dos "abomináveis pecados contra a natureza", nem mesmo o canibalismo, nem a ausência de um ordenado consórcio social (ou seja as "feridades"), nem a idolatria constituíam uma base suficiente para privar do dominium aqueles que, embora "bárbaros", eram, para todos os efeitos, homens de pleno direito. ${ }^{71}$ Aquelas conclusões poderiam ter sido estendidas também aos negros africanos, mas o perdurar do silêncio a seu respeito é a confirmação da falta de vontade de se enfrentar o caso específico.

$\mathrm{Na}$ década seguinte, as posições mantidas por Nóbrega, na disputa de Bahia com o jesuíta Quiricio Caxa, forneceram a base legal para o primeiro provi-

\footnotetext{
${ }^{69}$ Fernando Oliveira, Arte da guerra do mar, em Coimbra, per Iohão Alverez, 1555, f. 15v.

${ }^{70}$ Para aprofundamentos, remeto a meu ensaio "Conversione e schiavitù. La confraternita della Nossa Senhora do Rosário nella Lisbona del '500”, In: Stephania Pastore et alii (eds.), Brotherhood and Boundaries. Atti del convegno internazionale, Pisa, Edizioni della Normale, 2011, pp. 351-367.

${ }^{71}$ Tratado sobre a guerra que será justa, publicado em As Gavetas, t. 2, pp. 676-685. Para a data e atribuição, permito-me remeter ao que defendi em minha tese La coscienza di un impero, pp. 211-212.
} 
mento emanado em defesa dos índios do Brasil (1570). ${ }^{72} \mathrm{O}$ sistema do aldeamento visava garantir a condição de homens livres aos nativos que lá moravam, embora em estado de tutela (o que na prática sancionava sua consolidada inferioridade social), mas era frequentemente violado pelos colonos que tratavam pior que escravos aqueles que trabalhavam a seu serviço como assalariados. Os direitos dos índios aldeados deveriam portanto ser protegidos pelo procurador (cargo instituído em 1556), uma figura cuja analogia com aquela do "pai dos cristãos" na Ásia portuguesa mereceria ser investigada. ${ }^{73}$ Embora fuja em parte ao assunto do presente artigo, deve-se de fato lembrar como o mundo da escravidão portuguesa se estendia também às colônias que se debruçavam sobre o Oceano Índico, incluindo não somente os negros africanos lá exportados, mas também os povos locais, com um procedimento previsto em caso de conversão, sobre o qual, naqueles anos, convergia a aprovação de uma instituição que, por vários caminhos, presidia a manutenção de uma hierarquia com base étnica da sociedade lusitana, tanto nos trópicos como na madre pátria: a Inquisição. ${ }^{74}$

Na segunda metade do século XVI, a contribuição dos teólogos dominicanos ao debate sobre os povos do Novo Mundo foi se esgotando, enquanto assumia sempre mais vigor a reflexão dos jesuítas. Conforme demonstrou Zeron, apenas uma minoria desses jesuítas - todos com experiência em missões no Brasil - se posicionou em absoluto contra a possibilidade de se escravizar os índios, enquanto que em Portugal e em Roma um sólido bloco de padres defendia com diferentes argumentos a possibilidade de se providenciar escravos ora mediante guerra justa, ora mediante resgate. ${ }^{75}$ De fato, até os colégios da Companhia de Jesus usualmente começaram a possuir escravos índios, embora, em geral, os missionários

\footnotetext{
${ }^{72}$ Os documentos da disputa podem-se ler em Nóbrega, Cartas, doc. 41, pp. 399-429.

${ }^{73}$ Sobre o pai dos cristãos cf. Maria Benedita de Araújo, "O "Pay dos Christãos". Contribuição para o estudo da Cristianização da Índia”, In: Missionação Portuguesa e Encontro de Culturas. Actas do Congresso Internacional, Braga, UCP, 1993, vol. 2, pp. 305-324.

${ }^{74}$ Remonta provavelmente aos anos 1580, e se refere à India, o tomo de consulta dos deputados do Conselho Geral do Santo Ofício, titulado "Determinação acerca dos escravos cativos de infieis que se tornão christãos”, In: ANTT, CGSO, liv. 207, ff. 28-38v. O único parecer assinado é o do jesuíta Jorge Serrão, afirmando nele que "o cativo infiel que he escravo de qualquer infiel, se se tornar christão eo ipso consequitur libertatem nullo dato praetio domino infideli” (c. 36), mas também admite que se o dono infiel vendia o escravo convertido no prazo de três meses, podia receber em troca algum pagamento.
}

${ }^{75}$ Zeron, op. cit., p. 137. 
se servissem do trabalho forçado dos negros africanos. No caso desses últimos, os jesuítas unanimamente justificavam sua redução à escravidão sem levantar as mesmas dúvidas que pairavam sobre as modalidades com que era usual escravizar os índios. Atitude que foi acompanhada por uma indiferença teórica sobre as possibilidades de salvação dos negros africanos, que se manteve por muito tempo.

Prova do preconceito em relação a estes últimos são os comentários teológicos dos padres que ensinaram naqueles anos nas universidades portuguesas. $\mathrm{O}$ caso mais eloquente é talvez o de Pedro Simões, autor de um tratado sobre a restitutio escrito entre 1577 e 1578. Enquanto nos anos anteriores, em Lima, o confrade José de Acosta redigia o De procuranda Indorum salute, em Portugal, o comentário de Simões revelava como, em um quarto de século, a teologia moral passara de uma tendência à suspeita no seu afrontamento com os traficantes que iam para a África ocidental procurar escravos, expressa em termos diferentes tanto por Soto como por Oliveira, a uma total adesão às razões tanto dos traficantes como dos senhores de escravos, uma categoria que se tornou tanto mais poderosa e difícil de se criticar em público, quanto mais o uso da mão de obra dos escravos negros africanos se transformava em uma característica global do mundo ibérico. A propensão de Simões para uma interpretação de tipo etnográfico, em consonância com os interesses de traficantes e donos de escravos, o induzia a afirmar, acerca do comportamento dos negreiros (definidos em maneira sintomática de "mercadores cristãos"), que "não se deve presumir nada de mal, se nada consta claramente" (non est praesumendum, ni aliud constet). Da mesma forma, os compradores, em Lisboa, eram instados a se sentir "com consciência certa" (tutos in conscientia) enquanto não aparecessem sinais evidentes de que um homem de sua propriedade tivesse sido reduzido à escravidão de maneira ilícita. Nesse ponto Simões apoiava o princípio de discriminação até o ponto de negar que fosse "indício suficiente de um título injusto, se um escravo declarar ter sido preso de maneira ilegítima, pois se deve presumir que diz uma mentira para obter a liberdade". ${ }^{76}$

A parcialidade de um teólogo como Simões contrastava com a sensibilidade bem diferente que ia se afirmando na reflexão católica sobre os ameríndios, assim

\footnotetext{
76 "Sufficiens indicium de titulo iniusto, quando servus affirmat se iniuste fuisse captum, nam praesumendum est ipsum mentiri propter libertatem" (Pedro Simões, In materiam de restitutione, In: Biblioteca Nacional de Portugal, cod. 3.858, f. 10rv). Encontrando uma insistência análoga a respeito da presunção de inocência dos comerciantes portugueses de escravos em Fernando Pérez, Zeron falou de "angélisme" do teólogo jesuíta (op. cit., p. 269).
} 
como com as primeiras tentativas de realizar programas especiais de catequese organizados pelos próprios jesuítas em Lisboa para os escravos negros africanos que residiam na cidade. ${ }^{77}$ Foi naquele clima conflituoso que o importante posicionamento de Luis de Molina permitiu uma superação definitiva do enraizado descuido com os negros africanos, acerca de se saber se teriam ou não as condições necessárias para a salvação da alma, com inevitáveis reflexos tanto no plano social, como na esfera das teorias etnográficas. Exatamente em resposta à ambiguidade que favorecia leituras desresponsabilizantes como aquela de Simões, Molina forneceu um atento exame dos justos títulos alegados para a redução à escravidão e à aquisição dos negros africanos, com especial atenção para os vários contextos geográficos e hábitos locais, em uma avaliação que levava sempre em consideração a medida do direito natural. Ele julgou lícitas apenas as capturas feitas pelos portugueses numa guerra justa, como por ocasião da expedição militar no reino de Munumutapa (1570-1574) ou da conquista de Angola, comandada por Paulo Dias de Novais (1575). Ao contrário, condenou a indiferença moral dos traficantes e das autoridades eclesiásticas e civis lusitanas (com a relevante exceção da coroa, absolvida por ser pouco informada sobre os fatos). Apesar de uma substancial absolvição dos compradores no varejo, impossibilitados de desenvolver oportunas investigações sobre as circunstâncias da redução à escravidão e da aquisição dos escravos na África, Molina foi abertamente acusado por traficantes e grandes proprietários de terra de ter escrito "mil falsidades", conforme lembrou anos depois o confrade Alonso de Sandoval, autor de uma obra que marcou uma guinada decisiva para o reconhecimento da plena posse da graça também por parte dos negros africanos. Com um tratado redigido a partir do ponto de observação privilegiado de Cartagena das Índias, mas levando em consideração os debates do Brasil, Sandoval elaborou uma proposta para os negros africanos análoga àquela formulada algumas décadas antes por Acosta, cujo modelo era evocado desde o título: De instauranda Aethiopum salute (1627). ${ }^{78}$

\footnotetext{
${ }^{77}$ Liam M. Brockey, “Jesuit Pastoral Theater on an Urban Stage: Lisbon, 1588-1593”, Journal of Early Modern History, n. 9, 2005, pp. 1-50.

${ }^{78}$ Alonso de Sandoval, Naturaleza, policia sagrada i profana, costumbres $i$ ritos, discilpina i catechismo evangelico de todos etiopes, en Sevilla, por Francisco de Lira, 1627. O trecho se encontra na f. 70, no âmago de um capítulo dedicado inteiramente ao nó da justificação da escravidão dos negros africanos (lib. 1, cap. 17). Para uma análise recente do tratado, cf. Margaret M. Olsen, Slavery and Salvation in Colonial Cartagena de Indias, Gainesville: University Press of Florida, 2004. Ainda válido David G. Sweet, "Black Robes and 'Black Destiny': Jesuit Views of African Slavery in 17thCentury Latin America”, Revista de Historia de América, n. 86, 1978, pp. 87-133.
} 
Se do ponto de vista estritamente teórico a obra de Sandoval não acrescentou muita coisa às discussões da época sobre o dominium e sobre a licitude de se sujeitar as populações não europeias, não há dúvida sobre sua importância no plano de uma reavaliação da figura dos negros africanos nas sociedades iberoamericanas, representando assim o ponto de chegada de uma história conectada à reflexão teórica sobre a salvação de índios e negros africanos em seu especial entrelaçamento com a questão da escravidão. Sandoval, como Molina, deu grande atenção à proveniência geográfica dos africanos, colocou no centro do tratado uma impiedosa análise do comércio atlântico - o maior dos "grandes males que padecen estos negros" -, para enfim se concentrar sobre as formas mais eficazes e lhes garantir uma adequada preparação religiosa. ${ }^{79}$ Observava como os negros da Guiné eram os "que mais estiman los Españoles, por los que mas trabajan, los que les cuestan mas y los que comunmente llamamos de ley, de buenos naturales, de agudo ingenio, hermosos y bien dispuestos, alegres de coraçon y muy regozijados, sin perder ocasion en que si pueden, no tannan, canten y baylen, y esto aun en los exercicios mas trabajoso del mundo". ${ }^{80}$ Mas ao mesmo tempo - argumentava ainda - "quando estos negros han tratado por algun tiempo con nuestros españoles, no les son dessemejantes en los entendimientos y afectos de devocion, antes se experimenta en ellos capacidad grande, y un piadoso afecto a las cosas de la fè, y algunos han aprovechado mucho en la virtud". ${ }^{1}$

A vibrante defesa da possibilidade de salvação para os escravos negros africanos e a denúncia do tratamento a eles imposto pelos colonos ibéricos constituíam o resultado de uma nova consideração sobre uma humanidade danada, apresentada numa comparação acirrada com os ameríndios que os precederam no mesmo caminho dramático: "huvo el mismo descuydo en baptizar los indios

\footnotetext{
${ }^{79}$ Esse último objetivo era declarado como o principal desde o prólogo: "He le puesto a esta obra por titulo De instauranda Aetiopum salute, que es dezir: Tratado de como se à de restaurar la salvacion de los negros; porque el primario y principal fin della no es mover a que vamos a sus tierras a convertillos (aunque no dexa de ser esse el secundrio, y aun el principal, en quanto si assi fuera, escusado seria la mitad de este nuestro trabajo) sino que en las partes donde traen sus armaçones y ellos desembarcan, con nombre y titulo de christianos sin serlos (como en ella se verá), examinemos sus bautismos, instruyamos su rudeza y, bien enseñados, los baptizemos, con lo qual repararemos y restauraremos la salud que en ellos, por la razon dicha, estava perdida y como impossibilitada" (Sandoval, op. cit., Argumento de la obra al christiano letor).

${ }^{80}$ Sandoval, op. cit., f. $41 \mathrm{v}$.

${ }^{81}$ Idem, f. 242.
} 
adultos al principio, que ha avido e ay en el presente oy en baptizar los negros". ${ }^{82}$ $\mathrm{Na}$ perspectiva desse conhecimento do processo histórico acontecido no decorrer de pouco menos de um século, o trecho que segue constitui talvez a melhor síntese dos efeitos do pacto de silêncio da teologia da conversão sobre a formação da hierarquia social dos grupos humanos no Império português:

Bien sabemos que por el mal tratamiento que a los indios han hecho los españoles, se han ya apurado tanto, que en muchas provincias hay muy pocos, y en otras casi ningunos; y que en lugar de esos indios entraron estos pobres negros, en tan grande cantidad, que les labran sus tierras, les sacan el oro con que se enriquecen y les sustentan con su trabajo, sudor e industria; y en lugar de ampararlos, curarlos y defenderlos, como a sus esclavos y personas que les enriquecen y honran, los desamparan; y a trueco de no gastar cuatro reales y de no tener un poco de cuidado, los dexan morir recocidos en sus mesmos excrementos $[\ldots]{ }^{83}$

A imagem de vil abandono da alma dos escravos negros africanos, deixados para morrer entre seus humores e seus excrementos, reflete o peso que a conversão podia ter na formação de uma ordem interna da sociedade portuguesa, determinando as formas da segregação em setores discriminados com base na origem geográfica e religiosa.

No caso dos dois grupos que ocupavam os patamares mais baixos da escada social - os escravos índios e negros africanos -, o trabalho foi o fundamento comum para os modelos de relação propostos tanto pelos colonos como pelos missionários. Contudo, apesar das convergências até significativas, entre as respectivas abordagens, uma distância profunda subsistia. Podemos concluir que, mesmo com a ausência de uma teoria finita e compartilhada das relações sociais entre os vários grupos humanos, as normas de discriminação que gradualmente foram se difundindo no mundo português, tornando sempre mais estratificada a condição de súdito da coroa, baseavam-se numa mistura mutante, composta por um modelo fornecido seja pela transformação do preconceito antijudaico em uma obsessão institucional, seja pela complexa e controvertida reflexão de teólogos, juristas e missionários a respeito das possibilidades de salvação de categorias consideradas inferiores. Naquela mistura ambígua, mas peculiar de exploração, sangue e religião, que mais do que em outros lugares, se materializou na grande

\footnotetext{
${ }^{82} \mathrm{Idem}, \mathrm{f}$. 151v. Um trecho quase idêntico pode-se ler também no f. $263 \mathrm{v}$

${ }^{83} \mathrm{Idem}, \mathrm{f} .136 \mathrm{v}$.
} 
situação contraditória do Brasil colonial, onde a realidade oficial da segregação foi constantemente negada pelas nuanças de cores da pele cada vez mais variadas de seus moradores, deve-se talvez identificar a mais duradoura contribuição dada pela história do mundo português à gênese do racismo moderno. ${ }^{84}$

${ }^{84}$ As consequências da escravidão e da discriminação racial deixaram rastros evidentes também depois da independência do Brasil e da sua primeira constituição. Cf. Hebe Maria Mattos, Escravidão e Cidadania no Brasil Monárquico, Rio de Janeiro: Zahar, 2000. 